\title{
The relation of career indecision and parental attachment among Iranian undergraduate students.
}

\begin{abstract}
Career indecision particularly among college and undergraduate students is a concern of counselors and psychologists. This concern has led to numerous research studies related to career indecision and factors that influence it, such as family relationships. In this regard, several studies have reported a significant relationship between career indecision and parental attachment. However, little research has been undertaken on the influence of this factor in regard to career indecision for Iranian students. For this purpose, 158 Iranian freshmen and sophomores who had completed the 'Career Decision Scale' (Osipow et al., Journal of Vocational Behavior 9:233-243, 1976) and had been identified as career-undecided, completed the 'Inventory of Parents and Peer Attachment-Revised' (Armsden \& Greenberg, Journal of Youth and Adolescence 16:427-453, 1987). The results revealed that a significant negative relationship was found between career indecision and attachment to mother, whilst the relationship between career indecision and attachment to father was not significant. However, regression analysis showed parental attachment did not significantly predict career indecision of students. Implications and recommendations for further research are discussed.
\end{abstract}

Keyword: Career decision-making; Career indecision; Parental attachment; Paternal attachment; Maternal attachment; Attachment theory. 